\title{
Analisis Penerapan Sistem Proteksi Aktif, Sarana Penyelamatan Jiwa dan Pengorganisasian di Gedung Fakultas Ilmu Komputer Universitas Pembangunan Nasional Veteran Jakarta Tahun 2018
}

\author{
Alfina Yulita, Fandita Tonyka Maharani, Dyah Utari \\ Universitas Pembangunan Nasional Veteran Jakarta
}

\begin{abstract}
Abstrak
Latar Belakang: Data Departemen Dinas Pemadam Kebakaran dan Penyelamatan Jakarta memiliki 780 gedung bertingkat dan 222 gedung yang belum memenuhi persyaratan keamanan. Tujuan dari penelitian ini adalah untuk menganalisis implementasi sistem perlindungan aktif, fasilitas penyelamatan hidup, dan pengorganisasian di gedung Fakultas Ilmu Komputer Universitas Pembangunan Nasional Veteran Jakarta.

Metode: Penelitian ini menggunakan desain penelitian deskriptif dan pendekatan kualitatif dengan observasi langsung, review dokumen, wawancara mendalam, dan checklist. Hasil penelitian ini dibandingkan kesesuaiannya dengan Peraturan Menteri PU No. 26 / PRT / M / 2008, Peraturan Menteri No. 20 / PRT / M / 2009 dan NFPA 101 sebagai perbandingan untuk titik perakitan.

Hasil: Hasil penelitian ini menemukan bahwa Gedung Fakultas Ilmu Komputer Universitas Pembangunan Nasional Veteran Jakarta belum memiliki pengorganisasian api yang sesuai dengan standar. Sistem perlindungan aktif yang tidak terpenuhi adalah alarm kebakaran, sprinkler, detektor kebakaran, sistem pipa tegak dan hidran. Fasilitas penyelamatan jiwa yang tidak terpenuhi adalah pintu darurat, arah keluar, tangga darurat, dan penerangan darurat.

Kesimpulan: kesimpulan dari penelitian diperlukan prioritas untuk menyediakan pengorganisasian api, sistem perlindungan aktif, dan fasilitas penyelamatan jiwa yang belum memenuhi peraturan dan melakukan perawatan, inspeksi, dan uji coba untuk hal-hal yang terpenuhi.
\end{abstract}

Kata kunci: Kebakaran, Sistem Proteksi Kebakaran Aktif, Fasilitas Penghematan Langsung

\begin{abstract}
Background: Jakarta Dept. of Fire and Rescue Services Department data have 780 multi-storey buildings and 222 buildings that have not met the security requirements. The purpose of this research is to analyze implementation of active protection system, facility of life saving, and organizing in Faculty of Computer Science building University of Pembangunan Nasional Veteran Jakarta.

Methods: This research used descriptive study design and qualitative approach with direct observation, document review, indepth interviews, and checklist.

Result: The result of this research are compared its comformity with Peraturan Menteri PU No. 26/PRT/M/2008, Peraturan Menteri No. 20/PRT/M/2009 and NFPA 101 as comparison for assembly point. Result of this research are found that Faculty of Computer Science Building University of Pembangunan Nasional Veteran Jakarta yet to have organizing of fire that match with the standard. Active protection system that unfulfilled are fire alarm, sprinkler, fire detector, standpipe system and hydrant. Facility of life saving that unfulfilled are emergency door, exit direction, emergency stair, and emergency lighting.

Conclusion: From this research then is required to provide organizing of fire, active protection system, and facility of life saving that not yet fill the regulations and do maintenance, inspection, and trials for things fulfilled.
\end{abstract}

Keywords: Fire, Active Fire Protection System, Facility of Live Saving

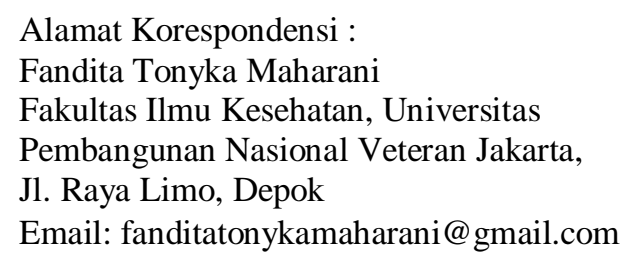




\section{PENDAHULUAN}

Pertumbuhan penduduk di Indonesia khususnya DKI Jakarta sangat pesat setiap tahunnya yang mendorong pemerintah setempat untuk membangun gedung -gedung yang dapat digunakan untuk berbagai kegiatan, pembangunan gedung bertingkat di berbagai kota besar di Indonesia semakin banyak bermunculan seperti gedung perkantoran ataupun gedung pemukiman dalam bentuk apartemen. ${ }^{1}$ Untuk terciptanya ruang lingkup kerja yang aman, selamat dan sejahtera, maka bangunan gedung harus memiliki aspek keselamatan kerja. Suatu gedung mempunyai kemampuan dalam menahan beban yang bekerja pada gedung itu sendiri, kemampuan dalam menanggulangi bahaya petir serta terhadap bahaya terjadinya kebakaran dalam upaya untuk melakukan keselamatan gedung. ${ }^{2}$

Kebakaran adalah bahaya yang dapat
membawa bencana yang besar dan
menyebabkan beberapa kerugian, baik
terhadap keselamatan jiwa maupun harta
benda. ${ }^{3}$ Bencana kebakaran dapat disebabkan
oleh berbagai faktor, yaitu diantaranya faktor
manusia maupun faktor teknis. Adapun
kerugian yang timbul akibat terjadinya
kebakaran yaitu berupa kerugian jiwa,
kerugian materi, menurunnya produktivitas,
gangguan bisnis, dan kerugian sosial.

Data statistik dari CTIF (International Association of Fire and Rescue Services) terjadi kejadian kebakaran di dunia di 43 negara pada tahun 2011 sampai 2015. Kejadian kebakaran terbanyak terjadi pada tahun 2011 yaitu 3.375.522 kasus, dan pada tahun 2015 terjadi kejadian kebakaran sebanyak 2.903.450 kasus. Dalam kejadian kebakaran ini menelan korban luka - luka sebanyak 43.802 orang dan korban meninggal sebanyak 18.475 orang pada tahun $2015 .{ }^{4}$

Kasus kebakaran yang terjadi di Indonesia sendiri pada tahun 1998 sampai tahun 2008 ditemukan sebanyak 8.243 kasus dengan menelan kerugian sebesar Rp. 1.255.091.940.080. ${ }^{5}$ Berdasarkan data Dinas Penanggulangan Kebakaran dan Penyelamatan Provinsi DKI Jakarta, dari 1.471 frekuensi kejadian kebakaran sepanjang 2017 terdapat 927 kasus yang diakibatkan oleh gangguan listrik. ${ }^{6}$

Kejadian kebakaran di Gedung C Fakultas Ilmu Sosial dan Ilmu Politik (FISIP) Universitas Indonesia pada pukul 06.38 WIB, Selasa 7 Januari 2014. Kebakaran tersebut diduga terjadi karena AC mengalami korsleting. Kerugian dari kejadian kebakaran tersebut yaitu berbagai arsip - arsip penting yang berada di pusat kajian sosiologi tersebut lenyap terbakar oleh api. ${ }^{7}$ Di Gedung Bahasa Asing Fakultas Bahasa dan Sastra (FBS) Universitas Negeri Makassar (UNM) terbakar pada pukul 1.15 WIT, Minggu 19 November 2017, kebakaran berawal dari adanya bunyi keras di kantor tersebut. Kemudian, tercium bau seperti kabel terbakar. Tak lama berselang, listrik di gedung itu padam dan tiba-tiba muncul api. ${ }^{8}$

Universitas Pembangunan Nasional Veteran Jakarta merupakan salah satu universitas negeri yang terletak di Jakarta Selatan, yang didalamnya memiliki beberapa gedung bertingkat dimana setiap gedungnya memiliki fungsi yang berbeda. Dari perbedaan fungsi gedung tersebut dapat dipastikan bahwa risiko disetiap gedungnya pasti berbeda - beda. Salah satu gedung bertingkat yang ada di UPNVJ adalah Gedung Fakultas Ilmu Komputer, merupakan jurusan yang mempelajari segala hal yang berkaitan dengan komputer baik dari segi hardware maupun softwarenya. Di dalam gedung ini terdapat potensi bahaya yang dapat memicu ataupun menyebabkan terjadinya kebakaran, diantaranya adalah buku-buku di dalam perpustakaan, arsip-arsip dosen, laboratorium komputer dan instalasi listrik di setiap ruang gedung. Sehingga apabila terjadi kebakaran, dampak yang ditimbulkan akan besar. Oleh karena itu, penulis tertarik untuk melakukan penelitian "Analisis Upaya Meminimalisir Dampak Kebakaran Di Gedung Fakultas Ilmu Komputer Universitas Pembangunan Nasional Veteran Jakarta Tahun 2018".

Penyebab kasus kebakaran yang sering terjadi di DKI Jakarta adalah korsleting listrik. Kepala Seksi Operasional Dinas Penanggulangan Kebakaran dan 
Penyelamatan DKI Jakarta mengatakan, berdasarkan data yang ada, sejak bulan Januari sampai bulan Agustus 2017 terjadi 588 kasus kebakaran yang penyebabnya adalah hubungan arus pendek listrik. ${ }^{9}$

Tujuan dilakukannya penelitian ini adalah untuk menganalisis kesesuaian penerapan sistem proteksi aktif, sarana penyelamatan jiwa dan pengorganisasian di Gedung Fakultas Ilmu Komputer Universitas Pembangunan Nasional Veteran Jakarta dengan standar peraturan yang peneliti jabarkan pada ruang lingkup penelitian.

\section{METODE}

Penelitian ini menggunakan desain studi deskriptif dengan pendekatan kualitatif. Pengambilan data dalam penelitian ini menggunakan data primer dan sekunder. Data primer berdasarkan hasil observasi dan wawancara kepada pengelola gedung dan pihak terkait lainnya, sedangkan data sekunder berupa dokumen instansi terkait dan studi literatur mengenai standar atau peraturan yang sesuai dengan kebakaran. Data yang sudah dikumpulkan lalu dibandingkan dengan peraturan atau standar yang berlaku di Indonesia seperti Peraturan Menteri PU No. 26/PRT/M/2008, Peraturan Menteri No. 20/PRT/M/2009, Peraturan Daerah DKI Jakarta No. 8 Tahun 2008 dan NFPA 101 sebagai pembanding.

\section{HASIL}

Berdasarkan hasil observasi lapangan secara langsung, menunjukkan bahwa Gedung Fakultas Ilmu Komputer Universitas Pembangunan Nasional Veteran Jakarta memiliki rata - rata sistem proteksi aktif, sarana penyelamatan jiwa dan pengorganisasian dengan kategori kurang yang artinya persyaratan belum sesuai dengan standar acuan yang ada di Indonesia. Berikut merupakan tabel rata - rata kesesuaian di Gedung Fakultas Ilmu Komputer:

\section{Tabel 1 Rata - Rata Tingkat Kesesuaian Sistem Proteksi Aktif di Gedung Fakultas Ilmu Komputer}

\begin{tabular}{|l|l|l|}
\hline No. & Sistem Proteksi Aktif & Nilai Skoring \\
\hline 1. & APAR & $42 \%$ \\
\hline 2. & Sistem Pipa Tegak & $0 \%$ \\
\hline 3. & Hidran & $0 \%$ \\
\hline 4. & Alarm Kebakaran & $0 \%$ \\
\hline 5. & Sprinkler & $0 \%$ \\
\hline 6. & Detektor Kebakaran & $0 \%$ \\
\hline \multicolumn{2}{|c|}{ Rata - Rata } & $7 \%$ \\
\hline
\end{tabular}

Dari hasil rata - rata tingkat kesesuaian sistem proteksi aktif, Gedung Fakultas Ilmu Komputer UPNVJ mendapatkan skoring $7 \%$, berdasarkanTingkat Penilaian Audit Tentang Kebakaran Puslitbang Departemen Pekerjaan Umum, maka dapat ditarik kesimpulan tingkat kesesuainnya adalah kurang artinya terpasang namun ada sebagian instalasi yang tidak sesuai dengan standar peraturan.

Tabel 2 Rata - Rata Tingkat kesesuaian Sarana Penyelamatan Jiwa di Gedung Fakultas Ilmu Komputer

\begin{tabular}{|l|l|l|}
\hline No. & $\begin{array}{l}\text { Sarana Penyelamatan } \\
\text { Jiwa }\end{array}$ & Nilai Skoring \\
\hline 1. & Tangga Darurat & $0 \%$ \\
\hline 2. & $\begin{array}{l}\text { Petunjuk Arah Jalan } \\
\text { Keluuar }\end{array}$ & $0 \%$ \\
\hline 3. & Tempat Berhimpun & $100 \%$ \\
\hline 4. & Pintu Darurat & $0 \%$ \\
\hline 5. & Pencahayaan Darurat & $0 \%$ \\
\hline & Rata - Rata & $20 \%$ \\
\hline
\end{tabular}

Hasil rata - rata tingkat kesesuaian sarana penyelamatan jiwa yang ada di Gedung Fakultas Ilmu Komputer Universitas Pembangunan Nasional Veteran Jakarta diperoleh skoring sebesar 20\%. berdasarkan Tingkat Penilaian Audit Tentang Kebakaran Puslitbang Departemen Pekerjaan Umum, maka dapat ditarik kesimpulan tingkat kesesuainnya adalah kurang artinya terpasang namun ada sebagian instalasi yang tidak sesuai dengan standar peraturan. 
Tabel 3 Rata - Rata Tingkat Kesesuaian Pengorganisasian di Gedung Fakultas Ilmu Komputer

\begin{tabular}{|l|l|l|}
\hline No. & Pengorganisasian & $\begin{array}{l}\text { Nilai } \\
\text { Skorinng }\end{array}$ \\
\hline 1. & $\begin{array}{l}\text { Prosedur Tanggap } \\
\text { Darurat }\end{array}$ & $0 \%$ \\
\hline 2. & $\begin{array}{l}\text { Organisasi Proteksi } \\
\text { Kebakaran }\end{array}$ & $0 \%$ \\
\hline 3. & Sumber Daya Manusia & $0 \%$ \\
\hline 4. & Pelatihan Kebakaran & $25 \%$ \\
\hline & Rata - Rata & $6,25 \%$ \\
\hline
\end{tabular}

Berdasarkan tabel rata - rata tingkat kesesuaian pengorganisasian di Gedung Fakultas Ilmu Komputer diperoleh skor sebesar $6,25 \%$, dapat ditarik kesimpulan tingkat kesesuainnya adalah kurang artinya terpasang namun ada sebagian instalasi yang tidak sesuai dengan standar peraturan, hal ini berdasarkan Tingkat Penilaian Audit Tentang Kebakaran Puslitbang Departemen Pekerjaan Umum.

\section{PEMBAHASAN}

\section{Tingkat Kesesuaian Sistem Proteksi Aktif di Gedung Fakultas Ilmu Komputer}

Berdasarkan hasil wawancara dengan informan, hal ini dikarenakan tidak ada perencanaan dari awal pada saat pembangunan gedung dan terkendala pada biaya yang dibutuhkan tidak sedikit.

Alat Pemadam Api Ringan (APAR), di Gedung Fakultas Ilmu Komputer mendapatkan hasil skoring 42\%. Nilai ini didapatkan dari hasil penjumlahan item yang sesuai dibandingkan dengan jumlah keseluruhan data. Menurut penilaian berdasarkan tabel Tingkat Penilaian Audit Tentang Kebakaran Puslitbang Departemen Pekerjaan Umum, maka dapat ditarik kesimpulan tingkat kesesuainnya adalah kurang artinya terpasang namun ada sebagian instalasi yang tidak sesuai dengan standar peraturan yaitu Permen PU No. 26/PRT/M/2008 dan Permenakertrans No. PER.04/MEN/1980.

Beda halnya dengan penelitian Mandey (2017) mengenai analisis keandalan sistem keselamatan kebakaran bangunan menggunakan pd-t-11-2005-c di fkm unsrat manado yang menyatakan bahwa tidak tersedianya APAR di gedung tersebut. ${ }^{10}$ Tingkat kesesuaiannya adalah $0 \%$ yaitu tidak sesuai. Penelitian yang dilakukan oleh Odipatra (2017) mengenai analisis tingkat pemenuhan sarana proteksi kebakaran aktif dan sarana penyelamatan jiwa di gedung kampus fakultas kesehatan masyarakat universitas andalas tahun 2017 yang menyebutkan bahwa belum tersedianya APAR di gedung tersebut, tingkat pemenuhan untuk APAR di gedung Fakultas Kesehatan Masyarakat adalah $0 \%$ artinya tidak sesuai. ${ }^{11}$ Penelitian Camelia mengenai analisis sistem proteksi kebakaran pada bangunan gedung dan lingkungan di Universitas Sriwijaya Kampus Inderalaya tahun 2013 yang menyatakan bahwa APAR hanya terdapat pada gedung rektorat, penelitian tersebut tidak melakukan tingkat kesesuaian dengan standar peraturan, dalam penelitian tersebut kurangnya penerapan APAR di kampus Inderalaya. ${ }^{12}$

Sistem pipa tegak tidak terdapat di gedung Fakultas Ilmu Komputer Universitas Pembangunan Nasional Veteran Jakarta, memiliki skor kesesuaian sebesar $0 \%$. Menurut penilaian berdasarkan tabel Tingkat Penilaian Audit Tentang Kebakaran Puslitbang Departemen Pekerjaan Umum, maka dapat ditarik kesimpulan tingkat kesesuainnya adalah tidak sesuai dengan Permen PU No. 26/PRT/M/2008 dan SNI 031745-2000, hal ini dikarenakan tidak tersedianya sistem pipa tegak di gedung Fakultas Ilmu Komputer.

Hidran di gedung FIK UPNVJ mendapatkan skor 0\%, skor tersebut dari hasil penjumlahan data mengenai hidran yang sesuai dibandingkan dengan jumlah keseluruhan data. Menurut penilaian berdasarkan tabel Tingkat Penilaian Audit Tentang Kebakaran Puslitbang Departemen Pekerjaan Umum, maka dapat ditarik kesimpulan tingkat kesesuainnya adalah tidak sesuai dengan Permen PU No. 26/PRT/M/2008 dan SNI 03-1745-2000, karena Gedung Fakultas Ilmu Komputer tidak tidak memiliki hidran dan tidak adanya perencanaan awal yang matang pada saat pembangunan gedung. 
Gedung Fakultas Ilmu Komputer belum memiliki sarana alarm kebakaran. Karena memang tidak adanya perencanaan pemasangan alarm kebakaran, apabila terjadi keadaan darurat seperti kebakaran pemberitahuan hanya melalui telefon genggam, karkol dan melalui koordinasi dari pihak keamanan atau security. Gedung Fakultas Ilmu Komputer mendapatkan skor $0 \%$, skor didapatkan dari hasil penjumlahan data mengenai alarm kebakaran yang sesuai dibandingkan dengan jumlah keseluruhan data. Menurut penilaian berdasarkan tabel Tingkat Penilaian Audit Tentang Kebakaran Puslitbang Departemen Pekerjaan Umum, maka dapat ditarik kesimpulan tingkat kesesuainnya adalah tidak sesuai dengan Permen PU No. 26/PRT/M/2008 dan SNI 033985-2000.

Hidran di gedung Fakultas Ilmu Komputer mendapatkan skor $0 \%$, skor didapatkan dari hasil penjumlahan data mengenai springkler yang sesuai dibandingkan dengan jumlah keseluruhan data. Menurut penilaian berdasarkan tabel Tingkat Penilaian Audit Tentang Kebakaran Puslitbang Departemen Pekerjaan Umum, maka dapat ditarik kesimpulan tingkat kesesuainnya adalah tidak sesuai dengan Permen PU No. 26/PRT/M/2008 dan SNI 033989-2000.

Berdasarkan dari hasil observasi lapangan maupun wawancara diketahui bahwa gedung FIK UPNVJ belum memiliki sprinkler. Menurut Peraturan Menteri Pekerjaan Umum Nomor 26/PRT/M/2008 tentang persyaratan teknis sistem proteksi kebakaran, sprinkler adalah alat pemancar air untuk pemadam kebakaran yang mempunyai tudung berbentuk deflector pada ujung mulut pancarnya, sehingga air dapat memancar ke semua arah secara merata. Sprinkler merupakan sistem proteksi aktif yang dapat memancarkan air kesemua arah secara otomatis. Apabila terjadi keadaan darurat seperti kebakaran maka, sistem sprinkler sangat membantu. ${ }^{13}$

Sejalan dengan penelitian yang dilakukan oleh Odipatra mengenai analisis tingkat pemenuhan sarana proteksi kebakaran aktif dan sarana penyelamatan jiwa di gedung kampus Fakultas Kesehatan Masyarakat Universitas Andalas. Dalam penelitian tersebut menyebutkan bahwa tidak terdapat sprinkler di gedung FKM UNAND yang berfungsi untuk menyemprotkan air ke seluruh arah lokasi kejadian kebakaran secara merata, dengan tingkat kesesuaian sprinkler sebesar $0 \%$ yaitu tidak sesuai. ${ }^{11}$ Berbeda halnya dengan penelitian Liardi (2014) mengenai analisis risiko kebakaran dalam pemenuhan sistem tanggap darurat kebakaran di universitas dian nuswantoro semarang tahun 2014 yang menyebutkan bahwa tersedianya sprinkler dan dalam keadaan yang baik dengan tingkat kesesuaian $100 \%$ yaitu kategori baik. ${ }^{14}$

Detektor kebakaran di gedung Fakultas Ilmu Komputer mendapatkan skor 0\%, skor didapatkan dari hasil penjumlahan data mengenai detektor kebakaran yang sesuai dibandingkan dengan jumlah keseluruhan data. Menurut penilaian berdasarkan tabel Tingkat Penilaian Audit Tentang Kebakaran Puslitbang Departemen Pekerjaan Umum, maka dapat ditarik kesimpulan tingkat kesesuainnya adalah tidak sesuai dengan SNI 03-3985-2000. Tingkat pemenuhan detektor kebakaran adalah $0 \%$ yaitu tidak sesuai dengan persyaratan. Pada penelitian yang dilakukan oleh Lestari dan Amaral mengenai audit sarana prasarana pencegahan penanggulangan dan tanggap darurat kebakaran di gedung fakultas $\mathrm{x}$ Universitas Indonesia tahun 2006 bahwa sistem detektor hanya terdapat pada gedung $G$ sedangkan pada gedung lainnya belum tersedia. ${ }^{15}$

\section{Tingkat kesesuaian Sarana Penyelamatan Jiwa di Gedung Fakultas Ilmu Komputer}

Tangga yang tersedia di Gedung Fakultas Ilmu Komputer hanya untuk mobilisasi seluruh penghuni gedung, tangga tersebut terletak disisi gedung yaitu ditengah bagian gedung dan di bagian kanan gedung, mendapatkan skor $0 \%$ dari hasil kesesuaian perbandingan elemen pintu darurat, skor tersebut dari hasil penjumlahan data mengenai tangga darurat yang sesuai dibandingkan dengan jumlah keseluruhan data. Menurut penilaian berdasarkan tabel Tingkat Penilaian Audit Tentang Kebakaran Puslitbang Departemen Pekerjaan Umum, maka dapat ditarik kesimpulan tingkat kesesuainnya adalah tidak sesuai dengan Peraturan Menteri Pekerjaan Umum No. 26/PRT/M/2008 dan SNI 03-1746-2000. 
Hal ini sejalan dengan penelitian yang dilakukan oleh Anisa dalam penelitiannya mengenai gambaran manajemen tangggap darurat kebakaran di gedung Fakultas Farmasi Universitas Indonesia. Menyebutkan bahwa di gedung Fakultas Farmasi UI belum memiliki tangga darurat. Dengan tingkat kesesuaian 0\% yaitu tidak sesuai dengan persyaratan. ${ }^{16}$

Berbeda dengan penelitian Odipatra mengenai analisis tingkat pemenuhan sarana proteksi kebakaran aktif dan sarana penyelamatan jiwa di gedung kampus fakultas kesehatan masyarakat universitas andalas tahun 2017 yang menyebutkan bahwa telah tersedia tangga darurat dengan skor sebesar $44,45 \%$ yaitu dengan kategori kurang, artinya tersedia namun sebagian besar elemen tidak sesuai. ${ }^{11}$ Penelitian Liardi mengenai analisis risiko kebakaran dalam pemenuhan sistem tanggap darurat kebakaran di Universitas Dian Nuswantoro Semarang tahun 2014 yang menyatakan bahwa tersedia tangga darurat, baik dan tidak terhalang dengan skor $100 \%$ yaitu kategori baik artinya sudah terpenuhi. ${ }^{14}$

Petunjuk arah jalan keluar di gedung Fakultas Ilmu Komputer belum sesuai dengan standar Peraturan Menteri Pekerjaan Umum No. 26/PRT/M/2008 dan SNI 031746-2000 dan mendapatkan skor kesesuaian sebesar 0\%, skor tersebut dari hasil penjumlahan data mengenai petunjuk arah jalan keluar yang sesuai dibandingkan dengan jumlah keseluruhan data. Menurut penilaian berdasarkan tabel Tingkat Penilaian Audit Tentang Kebakaran Puslitbang Departemen Pekerjaan Umum, maka dapat ditarik kesimpulan tingkat kesesuainnya adalah tidak sesuai dengan Peraturan Menteri Pekerjaan Umum No. 26/PRT/M/2008 dan SNI 03-1746-2000.

Tidak sejalan dengan penelitian yang dilakukan oleh Anisa dalam penelitiannya mengenai gambaran manajemen tangggap darurat kebakaran di gedung Fakultas Farmasi Universitas Indonesia, yang menyebutkan bahwa di gedung Fakultas Farmasi UI tersedia petunjuk arah jalan keluar yang ditempatkan disepanjang koridor dan di tangga dengan tingkat kesesuaian $75 \%$ yaitu cukup, artinya sudah terpasang tanda petunjuk arah jalan keluar namun ada beberapa bagian yang tidak terpenuhi persyaratan. ${ }^{16}$ Begitu pula dengan hasil penelitian yang dilakukan oleh Anggara mengenai evaluasi keandalan keselamatan kebakaran pada gedung Fisip Ii Universitas Brawijaya, malang tahun 2015 yang menyebutkan bahwa arah petunjuk jalan keluar dengan tingkat kesesuaian dengan penilaian 96 dan dengan bobot sebesar $20,16 \%$ yaitu dengan kategori baik. ${ }^{2}$

Letak tempat berhimpun di gedung Fakultas Ilmu Komputer berada di tengah ruang lingkup kampus tepatnya di lapangan upacara yang juga berfungsi sebagai tempat parkir kendaraan mobil dan motor. Kondisi tempat berhimpun cukup aman, bebas dari asap dan mudah dijangkau. Disimpulkan bahwa dari 4 persyaratan menurut NFPA 101 mengenai tempat berhimpun seluruhnya terpenuhi sehingga Gedung FIK UPNVJ mendapatkan skor $100 \%$, skor tersebut dari hasil penjumlahan data mengenai. organisasi proteksi kebakaran yang sesuai dibandingkan dengan jumlah keseluruhan data. Menurut penilaian berdasarkan tabel Tingkat Penilaian Audit Tentang Kebakaran Puslitbang Departemen Pekerjaan Umum, maka dapat ditarik kesimpulan tingkat kesesuainnya adalah baik (B) atau sesuai dengan NFPA 101.

Sejalan dengan penelitian Anisa dalam penelitiannya mengenai gambaran manajemen tangggap darurat kebakaran di gedung Fakultas Farmasi Universitas Indonesia. Menyebutkan bahwa di gedung Fakultas Farmasi UI sudah tersedia tempat berhimpun sementara, dengan tingkat kesesuaian tempat berhimpun sebesar 100\% yaitu sesuai atau seluruh elemen terpenuhi persyaratan. ${ }^{16}$ Peneliti Amrullah mengenai analisis tingkat pemenuhan sarana proteksi aktif dan sarana penyelamatan jiwa di area PT. Sentrafood Indonusa tahun 2010 menyatakan bahwa di PT. Sentrafood Indonusa tersedia tempat berhimpun yang mendapatkan nilai skoring $100 \%$ dengan kategori baik. Penelitian Odipatra mengenai analisis tingkat pemenuhan sarana proteksi kebakaran aktif dan sarana penyelamatan jiwa di gedung kampus fakultas kesehatan masyarakat universitas andalas tahun 2017, menyatakan bahwa terdapat tempat berhimpun dengan tingkat kesesuaian cukup yaitu $66,67 \%$ skor yang dikategorikan cukup, artinya tersedia namun 
ada sebagian kecil elemen yang tidak sesuai. ${ }^{11}$

Berdasarkan hasil observasi lapangan di gedung Fakultas Ilmu Komputer UPNVJ tidak tersedia pintu darurat, memiliki tingkat kesesuaian sebesar 0\% dari hasil kesesuaian perbandingan elemen pintu darurat, skor tersebut dari hasil penjumlahan data mengenai prosedur tanggap darurat yang sesuai dibandingkan dengan jumlah keseluruhan data. Menurut penilaian berdasarkan tabel Tingkat Penilaian Audit Tentang Kebakaran Puslitbang Departemen Pekerjaan Umum, maka dapat ditarik kesimpulan tingkat kesesuainnya adalah tidak sesuai dengan Peraturan Menteri Pekerjaan Umum No. 26/PRT/M/2008 dan SNI 03-1746-2000.

Pencahayaan darurat di gedung Fakultas Ilmu Komputer belum tersedia. Hal ini disebabkan karena lampu yang digunakan sebagai penerangan hanya berasal dari pasokan PLN. Apabila terjadi pemadaman listrik maka pencahayaan akan padam karena tidak adanya pencahayan darurat. Sehingga akan menyulitkan proses evakuasi apabila terjadi keadaan darurat. Gedung Fakultas Ilmu Komputer UPNVJ mendapat nilai 0\%, skor tersebut dari hasil penjumlahan data mengenai prosedur tanggap darurat yang sesuai dibandingkan dengan jumlah keseluruhan data. Menurut penilaian berdasarkan tabel Tingkat Penilaian Audit Tentang Kebakaran Puslitbang Departemen Pekerjaan Umum, maka dapat ditarik kesimpulan tingkat kesesuainnya adalah tidak sesuai dengan Peraturan Menteri Pekerjaan Umum No. 26/PRT/M/2008 dan SNI 03-6574-2001.

Sejalan dengan penelitian Anisa dalam penelitiannya mengenai gambaran manajemen tangggap darurat kebakaran di gedung Fakultas Farmasi Universitas Indonesia yang menyebutkan bahwa belum memiliki pencahayaan darurat. Tingkat kesesuaian pencahayaan darurat sebesar $0 \%$ yaitu tidak sesuai dengan persyaratan. Penelitian yang dilakukan oleh Mandey mengenai analisis keandalan sistem keselamatan kebakaran bangunan menggunakan pd-t- 11-2005-c di fkm unsrat manado bahwa tidak tersedianya pencahayaan darurat, dari hasil kesesuaian didapatkan hasil skoring 0\% dengan kategori tidak sesuai. $^{10}$

Berbeda dengan penelitian yang dilakukan oleh Kusumaningsih mengenai analisis sistem pencegahan penanggulangan dan tanggap darurat terhadap kebakaran di Perpustakaan Pusat Universitas Indonesia tahun 2012, yang menyebutkan bahwa terdapat penerangan darurat disetiap lantainya, tangga darurat dan jalan keluar. Skor yang didapat adalah $100 \%$ dengan kategori baik yang artinya sesuai. ${ }^{17}$

\section{Tingkat Kesesuaian Pengorganisasian di Gedung Fakultas Ilmu Komputer}

Prosedur tanggap darurat di gedung Fakultas Ilmu Komputer belum tertulis dengan jelas, gedung Fakultas Ilmu Komputer UPNVJ mendapat nilai 0\%, skor tersebut dari hasil penjumlahan data mengenai prosedur tanggap darurat yang sesuai dibandingkan dengan jumlah keseluruhan data. Menurut penilaian berdasarkan tabel Tingkat Penilaian Audit Tentang KebakaranPuslitbang Departemen Pekerjaan Umum, maka dapat ditarik kesimpulan tingkat kesesuainnya adalah tidak sesuai dengan Permen PU No.20/PRT/M/2009.

Hal ini sejalan dengan penelitian yang dilakukan oleh Anisa dalam penelitiannya mengenai gambaran manajemen tangggap darurat kebakaran di gedung Fakultas Farmasi Universitas Indonesia dan Kurniawan dalam penelitiannya mengenai gambaran manajemen dan sistem proteksi kebakaran di gedung Fakultas Kedokteran dan Ilmu Kesehatan Universitas Islam Negri Jakarta. ${ }^{18}$ Kedua penelitian tersebut menyebutkan bahwa di gedung Fakultas tersebut tidak memiliki prosedur tanggap darurat. Tingkat pemenuhan prosedur tanggap darurat adalah $0 \%$ yaitu tidak sesuai. Begitupula dengan penelitian Liardi mengenai analisis risiko kebakaran dalam pemenuhan sistem tanggap darurat kebakaran di universitas dian nuswantoro semarang tahun 2014 mengatakan bahwa Gedung UDINUS Semarang belum memiliki prosedur tanggap darurat yang lengkap perihal pemberitahuan awal, pemadaman kebakaranmanual, pelaksanaan evakuasi, pemeriksaan dan pemeliharaan peralatan proteksi kebakaran, tingkat kesesuaian yang didapat adalah $0 \%$ yaitu tidak sesuai. $^{14}$

Organisasi proteksi kebakaran di gedung Fakultas Ilmu Komputer belum tersusun secara terstruktur dan sesuai dengan 
standar yang berlaku yaitu Peraturan Menteri Pekerjaan Umum No. 20/PRT/M/2009.

Petugas yang bertanggung jawab pada saat terjadi keadaan darurat termasuk kebakaran hanya tim pengamanan atau security. Berdasarkan hasil perbandingan mengenai organisasi proteksi kebakaran, didapatkan bahwa dari 10 persyaratan mengenai organisasi proteksi kebakaran, seluruhnya tidak terpenuhi atau tidak sesuai dengan standar acuan.

Penelitian ini sejalan dengan penelitian Anisa dalam penelitiannya mengenai gambaran manajemen tangggap darurat kebakaran di gedung Fakultas Farmasi Universitas Indonesia. Menyebutkan bahwa di gedung Fakultas Farmasi UI belum memiliki organisasi maupun tim tanggap darurat kebakaran secara struktural. Tingkat kesesuaian organisasi proteksi kebakaran sebesar $0 \%$ yaitu tidak sesuai. Begitu pula penelitian yang dilakukan oleh Kusumaningsih dalam penelitiannya mengenai analisis sistem pencegahan penanggulangan dan tanggap darurat terhadap kebakaran di perpustakaan pusat universitas indonesia tahun 2012, yang menyebutkan bahwa Perpustakaan Pusat UI secara struktural belum memiliki struktur organisasi maupun tim penanggulangan kebakaran, petugas yang bertanggung jawab saat terjadi bahaya kebakaran adalah security. Tingkat kesesuaian yang didapatkan bahwa organisasi kebakaran perpustakaan pusat UI adalah tidak terpenuhi. ${ }^{17}$

Penelitian selanjutnya yang sejalan adalah penelitian yang dilakukan oleh Liardi mengenai analisis risiko kebakaran dalam pemenuhan sistem tanggap darurat kebakaran di universitas dian nuswantoro semarang tahun 2014. Di gedung UDINUS Semarang belum memiliki organisasi dan tim penanggulangan kebakaran yang sesuai dengan standar yang berlaku. Petugas yang bertanggung jawab saat terjadi peristiwa kebakaran hanya tim pengaman (Security) gedung, karena sumber daya manusia yang ada di gedung UDINUS masih belum terlatih. ${ }^{14}$

Sumber daya manusia di gedung Fakultas Ilmu Komputer belum sesuai ataupun terpenuhi persyaratannya sesuai dengan standar acuan peraturan. Hal ini disebabkan Gedung Fakultas Ilmu Komputer Universitas
Pembangunan Nasional Veteran Jakarta belum memiliki sumber daya manusia secara khusus dengan dasar pengetahuan, pengalaman dan keahlian dibidang pengamanan dan penyelamatan kebakaran guna untuk penanggulangan dan pencegahan kebakaran. Gedung Fakultas Ilmu Komputer UPNVJ mendapatkan skor 0\%, skor tersebut dari hasil penjumlahan data mengenai sumber daya manusia yang sesuai dibandingkan dengan jumlah keseluruhan data. Menurut penilaian berdasarkan tabel Tingkat Penilaian Audit TentangKebakaran Puslitbang Departemen Pekerjaan Umum, maka dapat ditarik kesimpulan tingkat kesesuainnya adalah tidak sesuai dengan Peraturan Menteri Pekerjaan Umum No. 20/PRT/M/2009.

Sejalan dengan penelitian yang dilakukan oleh Anisa dalam penelitiannya mengenai gambaran manajemen tangggap darurat kebakaran di gedung Fakultas Farmasi Universitas Indonesia dan Kurniawan dalam penelitiannya mengenai gambaran manajemen dan sistem proteksi kebakaran di gedung Fakultas Kedokteran dan Ilmu Kesehatan Universitas Islam Negri Jakarta. Kedua penelitian tersebut menyebutkan bahwa belum adanya sumber daya manusia yang memiliki dasar pengetahuan, pengalaman dan keahlian terhadap keadaan darurat seperti kebakaran. Tingkat kesesuaian sumber daya manusia adalah $0 \%$ yaitu tidak sesuai.

Pelatihan kebakaran di Gedung Fakultas Ilmu Komputer mendapatkan skor sebesar 25\% dengan kategori kurang yang artinya sebagian elemen belum memenuhi persyaratan. Skor tersebut dari hasil penjumlahan data mengenai pelatihan kebakaran yang sesuai dibandingkan dengan jumlah keseluruhan data. Menurut penilaian berdasarkan tabel Tingkat Penilaian Audit Tentang Kebakaran Puslitbang Departemen Pekerjaan Umum, maka dapat ditarik kesimpulan tingkat kesesuainnya adalah kurang, yang artinya telah diterapkan namun ada beberapa elemen yang tidak sesuai dengan Peraturan Menteri Pekerjaan Umum No. 20/PRT/M/2009.

Tidak sejalan dengan penelitian Kusumaningsih dalam penelitiannya mengenai analisis sistem pencegahan penanggulangan dan tanggap darurat terhadap kebakaran 
di perpustakaan pusat Universitas Indonesia. Penelitian tersebut menyebutkan bahwa di perpustakaan pusat Universitas Indonesia belum memberikan pelatihan tanggap darurat kebakaran dan evakuasi kepada seluruh karyawan serta penghuninya. Tingkat kesesuaian pelatihan kebakaran dalam penelitian tersebut adalah $0 \%$ yaitu tidak sesuai. ${ }^{17}$ Berbeda dengan penelitian yang dilakukan oleh Liardi mengenai analisis risiko kebakaran dalam pemenuhan sistem tanggap darurat kebakaran di universitas dian nuswantoro semarang tahun 2014 yang menyatakan bahwa gedung UDINUS Semarang pernah mengadakan pelatihan penanggulangan kebakaran dan evakuasi secara periodik yaitu setahun sekali yang hanya diperuntukkan bagi karyawan, satpam (security), cleaning service dan mahasiswa fakultas kesehatan, tingkat kesesuaiannya adalah $25 \%$, dari 4 persyaratan hanya 1 yang sesuai. Tingkat kesesuaian tersebut dikategorikan kurang artinya terpasang namun sebagian besar elemen tidak memenuhi persyaratan

\section{KESIMPULAN}

Berdasarkan hasil penelitian terhadap analisis penerapan pengorganisasian, sistem proteksi aktif dan sarana penyelamatan jiwa di gedung Fakultas Ilmu Komputer Universitas Pembangunan Nasional Veteran Jakarta yang dilakukan melalui metode checklist berdasarkan standar peraturan, wawancara, observasi lapangan dan telaah dokumen, maka didapatkan hasil kesimpulan sebagai berikut:

a. Klasifikasi potensi bahaya kebakaran di gedung Fakultas Ilmu Komputer disetiap lantainya berbeda, sesuai dengan fungsi ruangan tersebut. Pada lantai 3 dan 4 diklasifikasikan bahaya kebakaran sedang I dikarenakan fungsi ruangan tersebut adalah laboratorium komputer, sedangkan ruangan yang lainnya diklasifikasikan bahaya kebakaran ringan.

b. Sistem proteksi Aktif yang dimiliki oleh Gedung Fakultas Ilmu Komputer yaitu APAR (Alat Pemadam Api Ringan), hasil dari tabel kesesuaian didapatkan skor 50\% dengan tingkat kesesuainnya adalah kurang.

c. Sarana Penyelamatan Jiwa di Gedung Fakultas Ilmu Komputer yaitu tempat berhimpun, skor yang didapatkan dari hasil tabel kesesuaian adalah 100\% dengan tingkat kesesuaiannya adalah sesuai.

d. Pengorganisasian di Gedung Fakultas Ilmu Komputer belum seluruhnya sesuai dengan standar peraturan yang berlaku, hanya melakukan pelatihan kebakaran dalam kurun waktu 1 tahun 2 kali, dari hasil tabel kesesuaian didapatkan skor $25 \%$ dengan tingkat kesesuaiannya adalah kurang, yang artinya telah diterapkan namun ada beberapa elemen yang tidak sesuai.

\section{DAFTAR PUSTAKA}

1. Ramli, S. 2010, Petunjuk Praktis Manajemen Kebakaran (fire management). 4th edn. Edited by R. Husjain, Djajaningrat, AMAK, SKM, M.Kes Praptono. Jakarta: Dian Rakyat.

2. Anggara, D. V. 2015. Evaluasi Keandalan Keselamatan Kebakaran Pada Gedung Fisip II. Skripsi. Malang: Universitas Brawijaya, Malang.

3. Kementerian Hukum dan Hak Asasi Manusia. 2008. Peraturan Daerah DKI Jakarta No. 8. 2008. Pencegahan dan Penanggulangan Bahaya Kebakaran.

4. Brushlinsky, N. 2017, World Fire Statistics. USA: International Association of Fire and Rescue Services.

5. Karimah, M. et al. 2016. Analisis Upaya Penanggulangan Kebakaran Di Gedung Bougenville Rumah Sakit Telogorejo Semarang. Jurnal Kesehatan Masyarakat. Vol.4, no.4, Oktober 2016, hlm. 2356-3346, diakses 2 Maret 2018 http://ejournals1.undip.ac.id/index.php/jkm

6. Maria, C. 2018. Ini Penyebab Tertinggi Kebakaran di Jakarta Selama 2017, metro.tempo.co. diakses 2 Maret 2018 https://metro.tempo.co/read/1056663/i nipenyebab-tertinggi-kebakaran-di- jakartaselama-2017

7. Anshari, D. F. R. El. 2014. Kronologi Kebakaran di Gedung C FISIP UI Kompas.com, Kompas.com, diakses 19 Maret 2018 https://megapolitan.kompas.com/rea d/2014/01/07/0921022/Kronologi.Ke

bakaran.di.Gedung.C.FISIP.UI

8. Dasrin. 2017. Begini Kronologi Kebakaran di Gedung Bahasa Asing FBS UNM - Profesi Online, profesi-unm.com, diakses 9 Maret 2018 http://www.profesiunm.com/2017/11/19/begini-kronologikebakaran-di-gedung- bahasa-asing-fbs-unm/ 
9. Sandita, A. 2017. Korsleting Listrik Jadi Penyebab Utama Kebakaran, metro.sindonews.com, diakses 11 Maret 2018 https://metro.sindonews.com $/ \mathrm{read} / 12$ 35313/170/korsleting-listrik-jadipenyebab-utama-kebakaran-dijakarta- 1504088680

10. Mandey, H. et al. 2017. Kebakaran Bangunan Menggunakan Pd-T-11- 2005-C Di Fkm Unsrat Manado Pembangunan Gedung Bertingkat. Jurnal Kesehatan, Vol.9, no.3, hlm. 1-13, diakses 2 Maret 2018.

https://ejournalhealth.com/index.php /medkes/article/view/275

11. Odipatra, R. 2017. Analisis Tingkat Pemenuhan Sarana Proteksi Kebakaran Aktif Dan Sarana Penyelamatan Jiwa Di Gedung Kampus Fakultas Kesehatan Masyarakat Universitas Andalas Tahun 2017. Skripsi. Padang: Universitas Andalas.

12. Septiadi, H., Sunarsih, E. and Camelia,2014. Analisis Sistem Proteksi Kebakaran Pada Bangunan Gedung Dan Lingkungan Di Universitas Sriwijaya.

13. Kementerian Pekerjaan Umum. 2008. Peraturan Menteri Pekerjaan Umum No. 26. 2008 Persyaratan Teknis Sistem Proteksi Kebakaran pada Bangunan Gedung dan Lingkungan.
14. Liardi, C. A. 2014. Kebakaran Di Universitas Dian Nuswantoro Semarang Tahun 2014. Skripsi. Semarang: Universitas Dian Nuswantoro Semarang.

15. Lestari, F. and Amaral, Y. 2008. Audit Sarana Prasarana Pencegahan Penanggulangan Dan Tanggap Darurat Kebakaran Di Gedung Fakultas X Universitas Indonesia Tahun 2006. Jurnal Makara Teknologi, Vol.12, no.1, hlm. 55-60, diakses 2 Maret 2018. http://puslit2.petra.ac.id/ejournal/ind ex.php/mkr/article/view/17693/1760 7

16. Anisa, D. 2016. Gambaran Manajemen Tanggap Darurat Kebakaran dan Sarana Penyelamatan Jiwa Di Gedung Fakultas Farmasi niversitas Indonesia Tahun 2016. Skripsi. Depok: Universitas Indonesia

17. Kusumaningsih, R. 2012. Analisis Sistem Pencegahan Penanggulangan Dan Tanggap Darurat Kebakaran Di Perpustakaan Pusat Universitas Indonesia Tahun 2012. Skripsi. Depok: Universitas Indonesia

18. Kurniawan, A. 2014. Gambaran Manajemen Dan Sistem Proteksi Kebakaran Di Gedung Fakultas Kedokteran Dan Ilmu Kesehatan Universitas Islam Negeri Jakarta Tahun 2014. Skripsi. Jakarta: Universitas Islam Negeri Syarif Hidayatullah Jakarta. 